\title{
ANALISIS PENGARUH FDR, NPF, TINGKAT BAGI HASIL, KUALITAS JASA DAN ATRIBUT PRODUK ISLAM TERHADAP TINGKAT PEMBIAYAAN MUDHARABAH PADA BANK UMUM SYARI'AH DI SEMARANG
}

\author{
Wahab 1
}

\begin{abstract}
Abstrak
Mudharabah dengan konsep bagi hasil merupakan sebuah konsep yang sangat tepat diterapkan oleh bank syariah untuk menggantikan sistem bunga pada bank konvensional. Mudharabah diharapkan bisa mendominasi pembiayaan yang ada di bank syariah, karena dengan sistim bagi hasil diharapkan lebih bisa menggerakean usaha yang bersifat produktif, sehingga tidak menutup kemungkinan untuk dapat menciptakan lapangan kerja yang baru. Selain itu apabila jumlab pembiayaan tinggi, hal ini akan menarik nasabah untuk lebih berani dalam menginvestasikan dana yang dimiliki ke dalam pembiayaan mudharabah. Namun jumlah pembiayaan mudharabah selalu lebih kecil daripada jumlah pembiayaan murabahah, yang merupakan pembiayaan dengan prinsip jual beli. Pembiayaan mudharabah banya mendapatkan jumlah sekitar 16\% di setiap tabunnya, sedangkan untuk pembiayaan murabahah adalah sekitar 58\% di setiap tahunnya. Pembiayaan mudharabah yang diharapkan dapat menjadi produk unggulan dari bank syariah justru tertinggal jumlabnya dari pembiayaan murabahah. Hal ini dapat terjadi karena ada beberapa faktor yang dapat mempengarubi jumlah pembiayaan mudharabah.

Hasil peneletian pengaruh kualitas jasa layanan terhadap pembiayaan mudharabah berdasarkan hasil penelitian, KJL mempunyai pengarub signifikan positif terhadap pembiayaan mudharabah pada BUS. Ditunjukkan dengan tingkat signifikansi dibawah 0,05 yaitu sebesar 0,038. yang berarti hipotesis yang menyatakan Kualitas Jasa Layanan pada BUS berpengarub signifikan positif terhadap pembiayaan mudharabah pada perbankan syariah di Indonesia di terima. Kata Kunci: Mudharabah, financing to deposit ratio, Non Performing Financing Tingkat Bagi Hasil, Kualitas Jasa Layanan, Atribut Produk Islam
\end{abstract}

Keyword : Mudharabah, financing to deposit ratio, Non Performing Financing Tingkat Bagi Hasil, Kualitas Jasa Layanan, Atribut Produk Islam

${ }^{1}$ Dosen Fakultas Ekonomi dan Bisnis Islam IAIN Walisongo Semarang

Volume V/Edisi 2/Oktober 2014 
Analisis Pengaruh FDR, NPF, Tingkat Bagi Hasil, Kualitas Jasa

\section{Pendahuluan}

Lembaga keuangan syariah di Indonesia hingga tahun 1998 perkembangannya masih belum pesat, karena baru ada satu Bank Syariah dan 78 Bank Perkreditan Rakyat S yariah (BPRS) yang beroperasi. Baru pada tahun 1998 dengan dikeluarkannya UU No. 10 tahun 1998 yang memberikan landasan hukum lebih kuat untuk perbankan syariah serta melalui UU No. 23 tahun 1999, Pemerintah memberikan kewenangan kepada Bank Indonesia untuk dapat menjalankan tugasnya berdasarkan prinsip syariah. Selanjutnya adalah Undang-Undang Perbankan Syariah Nomor 21 Tahun 2008 menerangkan ba hwa p erb ankan syariah ada lah se ga la sesuatu ya ng me nyangkut tentang Bank Syariah dan Unit Usaha Syariah, mencakup kelembagaan, kegiatan usaha, sertatata cara dan proses dalam melaksanakan kegiatan usahanya.

Kondisi perbankan syariah di Indonesia sampai dengan tahun 2013 sudah sangat baik serta mengalami banyak perkembangan. Hal ini dapat dilihat melalui jumlah Bank Umum Syariah (BUS), Unit Usaha Syariah (UUS), dan Bank Pembiayaan Rakyat Syariah (BPRS) yang semakin bertambah dari tahun ke tahun. Berikut ini adalah data mengenai pertumbuhan BUS dan UUS yang ada di Indonesia :

Tabel 1

Perkembangan BUS dan UUS di Indonesia pada tahun 2007 - 2013

\begin{tabular}{|l|l|l|l|l|l|l|l|}
\hline \multicolumn{1}{|c|}{ Indikator } & \multicolumn{1}{|c|}{2007} & \multicolumn{1}{|c|}{2008} & \multicolumn{1}{|c|}{2009} & \multicolumn{1}{|c|}{2010} & \multicolumn{1}{c|}{2011} & \multicolumn{1}{c|}{2012} & 2013 \\
\hline BUS & 3 & 5 & 6 & 11 & 11 & 11 & 11 \\
\hline UUS & 26 & 27 & 25 & 23 & 24 & 24 & 23 \\
\hline BPRS & 114 & 131 & 138 & 150 & 155 & 158 & 160 \\
\hline $\begin{array}{l}\text { Jariangan } \\
\text { kantor }\end{array}$ & 802 & 1069 & 1258 & 1763 & 1737 & 2262 & 2526 \\
\hline $\begin{array}{l}\text { Aset (Milyar } \\
\text { Rupiah) }\end{array}$ & 37,754 & 51,249 & 68,212 & 100,258 & 148,987 & 149,321 & 242.27 \\
\hline $\begin{array}{l}\text { DPK (Milyar } \\
\text { Rupiah) }\end{array}$ & 28,730 & 37,828 & 53,522 & 77,640 & 117,510 & 116,871 & 183.53 \\
\hline $\begin{array}{l}\text { PYD (Milyar } \\
\text { Rupiah) }\end{array}$ & 28,837 & 39,255 & 48,473 & 70,190 & 105,331 & 106,532 & 184.12 \\
\hline
\end{tabular}

Sumber: Outlook Perbankan Syariah Desember 2013 
Data di atas menunjukkan bahwa perkembangan jumlah perbankan syariah di Indonesia sudah sangat baik. Hal ini harus diimbangi dengan peningkatan kualitas sumber daya manusia yang memadai, sehingga perbankan syariah dapat menjalankan tugasnya dengan sebaik mungkin berdasarkan syariah-syariah Islam.

Produk perbankan syariah terdiri dari 8 macam pembiayaan pada perbankan syariah, yaitu akad wadiah, akad mudharabah, akad musyarakah, akad murabahah, akad salam, akad istishna, akad ijarah, dan akad qardh. Semua produk dibingkai dalam mekanisme transaksi yang sesuai dengan prinsip-prinsip syarih dan ketentuan perundangan-undangan yang berlaku di Indonesia.

Mudharabah pada dasarnya membutuhkan rasa saling percaya yang tinggi antara pemilik dana dan pengelola dana. Selain itu, pembagian keuntungan harus dalam bentuk nisbah/persentase yang telah disepakati. Dalam mudharabah keuntungan disebut nisbah bagi hasil karena besarnya keuntungan yang akan diterima oleh pemilik dana dan pengelola dana belum bisa diketahui dengan pasti. Sehingga besarnya keuntungan yang akan diterima tergantung pada laba yang dihasilkan.

Apabila terjadi kerugian pada akad mudharabah, yang menanggung kerugian itu hanya si pemilik dana, pengelola dana tidak menanggung kerugian tersebut, kecuali kerugian itu terjadi akibat kesalahan yang dilakukan si pengelola dana. Sedangkan rentan waktu yang digunakan dalam akad mudharabah sesuai dengan kesepakatan yang telah ditentukan oleh kedua belah pihak. Jadi tidak ada ketentuan khusus tentang lamanya waktu yang digunakan dalam akad ini. Sehingga lebih fleksibel dalam pelaksanaannya.

Tabel 2

Perkembangan Pembiayaan yang dikeluarkan

BUS dan UUS Tahun 2005 - 2012 
Analisis Pengaruh FDR, NPF, Tingkat Bagi Hasil, Kualitas Jasa

(dalam miliar rupiah)

\begin{tabular}{|l|c|c|c|c|c|c|c|c|}
\hline \multicolumn{1}{|c|}{ Tahun } & 2005 & 2006 & 2007 & 2008 & 2009 & 2010 & 2011 & 2012 \\
\hline Akad Mudharabah & 3,124 & 4,062 & 5,578 & 6,205 & 6,597 & 8,630 & 10,2889 & 12,022 \\
\hline Akad Musyarakah & 1,898 & 2,335 & 4,406 & 7,411 & 10,412 & 14,424 & 18,960 & 27,667 \\
\hline Akad Murabahah & 9,487 & 12,624 & $\begin{array}{r}16,55 \\
22,48\end{array}$ & 26,321 & 37,508 & 56,365 & 88,004 \\
\hline Akad Salam & 0 & 0 & 0 & 0 & 0 & 0 & 0 & 0 \\
\hline Akad Istishna & 282 & 337 & 351 & 369 & 423 & 347 & 326 & 376 \\
\hline Akad Ijarah & 316 & 836 & 516 & 765 & 1,305 & 2.341 & 3,839 & 7,344 \\
\hline Akad Qardh & 125 & 250 & 540 & 959 & 1,829 & 4,731 & 12,937 & 12,090 \\
\hline
\end{tabular}

Sumber : www.bi.go.id

Berdasarkan data di atas, jumlah pembiayaan mudharabah selalu lebih kecil daripada jumlah pembiayaan murabahah, yang merupakan pembiayaan dengan prinsip jual beli. Pembiayaan mudharabah hanya mendapatkan jumlah sekitar $16 \%$ di setiap tahunnya, sedangkan untuk pembiayaan murabahah adalah sekitar 58\% di setiap tahunnya. Pembiayaan mudharabah yang diharapkan dapat menjadi produk unggulan dari bank syariah justru tertinggal jumlahnya dari pembiayaan murabahah. Hal ini dapat terjadi karena ada beberapa faktor yang dapat mempengaruhi jumlah pembiayaan mudharabah.

Peningkatan kualitas layanan jasa yang diberikan Bank Syariah terhadap nasabah dapat dijadikan sebagai kebijakan alternatif dalam keberhasilan bisnis didunia perbankan saat ini maupun dimasa yang akan datang. Pelayanan pada nasabah disuatu bank dimata nasabah mencakup faktor-faktor yang secara tradisional mewarnai penilaian nasabah atas kualitas layanan yang diterima seperti: kecepatan, ketepatan, keramahan, kenyamanan.

Faktor pelayanan menjadi salah satu faktor non keuangan yang diduga berpengaruh terhadap pembiayaan mudharabah, tapi juga adanya faktor atribut produk islam yang melekat pada semua produk perbankan juga 
diduga memmpunya kontribusi yang mendorong nasabah dalam memanfaatkan produk pembiayaan perbakan syariah.

\section{Permasalahan}

Berdasarkan paparan yang telah diuraikan di atas, maka peneliti tertarik untuk melakukan penelitian dengan judul " Analisis Pengaruh FDR, NPF, Tingkat Bagi Hasil, Kualitas Jasa dan Atribut Produk Islam Terhadap Tingkat Pembiayaan Mudharabah pada Bank Umum Syari'ah di Semarang”

\section{Pembahasan}

\section{Teori Stewardship}

Teori stewardship didesain bagi para peneliti untuk menguji situasi di mana para eksekutif dalam perusahaan sebagai pelayan dapat termotivasi untuk bertindak dengan cara terbaik pada principalnya, Donaldson dan Davis (1991) dalam Usamah (2009).

Chinn (2000) dalam Usamah (2009) menerangkan bahwa stewardship theory dibangun di atas asumsi filosofis mengenai sifat manusia yakni bahwa manusia pada hakekatnya dapat dipercaya, mampu bertindak dengan penuh tanggung jawab, memiliki integritas dan kejujuran terhadap pihak lain.

Jadi pada intinya implikasi teori stewardship pada penelitian ini adalah didasarkan hubungan kepercayaan antara pemilik dana (shabibul maal) dan pengelola dana (mudharib). Pemilik dana memberikan kepercayaan kepada pengelola dana untuk mengelola dana tersebut ke dalam suatu usaha yang bersifat produktif demi mencapai tujuan yang sama yaitu kesejahteraan hidup. Pengelola dana harus bersifat amanah (dapat dipercaya) serta memiliki tanggung jawab yang tinggi dalam mengelola usaha tersebut, meskipun pengelola dana tidak akan menanggung risiko jika usaha tersebut mengalami kerugian.

Volume V/Edisi 2/Oktober 2014 
Analisis Pengaruh FDR, NPF, Tingkat Bagi Hasil, Kualitas Jasa

\section{Laporan Keuangan Perbankan Syariah (PSAK 101)}

Laporan keuangan perbankan syariah menurut PSAK 101 merupakan laporan keuangan yang menyajikan entitas syariah untuk tujuan umum yang disusun dan disajikan sesuai dengan PSAK. Entitas syariah yang dimaksud di PSAK ini adalah entitas yang melaksanakan transaksi syariah sebagai kegiatan usaha berdasarkan prinsip-prinsip syariah yang dinyatakan dalam anggaran dasarnya. Entitas Syariah yang disajikan meliputi :

1. Aset

2. Kewajiban

3. Dana syirkah temporer

4. Ekuitas

5. Pendapatan dan beban termasuk keuntungan dan kerugian

6. Arus kas

7. Dana zakat

8. Dana kebajikan

\section{Definisi dan Konsep Mudharabah}

Mudharabah adalah perjanjian pembiayaan / penanaman dana dari pemilik dana (shabibul maal) kepada pengelola dana (mudharib) untuk melakukan kegiatan usaha tertentu yang sesuai syariah, dengan pembagian hasil usaha antara kedua belah pihak berdasarkan nisbah yang telah disepakati sebelumnya.

\section{Prinsip Mudarabah}

Pada prinsipnya dalam mudharabah tidak boleh ada jaminan atas modal, namun demikian agar pengelola dana tidak melakukan penyimpangan, pemilik dana dapat meminta jaminan dari pengelola dana atau pihak ketiga. Tentu saja jaminan ini hanya dapat dicairkan apabila 
pengelola dana terbukti melakukan kesalahan yang disengaja, lalai atau melakukan pelanggaran terhadap hal-hal yang telah disepakati bersama dalam akad.

Rukun mudharabah ada empat, yaitu:

1. Pelaku, terdiri atas pemilik dana dan pengelola dana

2. Objek mudharabah, berupa modal dan kerja

3. Ijab Kabul/Serah Terima

4. Nisbah Keuntungan

Ketentuan syariah sebagai berikut,

1. Pelaku

a. Pelaku harus cakap hukum dan baligh

b. Pelaku akad mudharabah dapat dilakukan sesama atau dengan non muslim

c. Pemilik dana tidak boleh ikut campur dalam pengelolaan usaha tetapi ia boleh mengawasi

2. Objek mudharabah (Modal dan Kerja)

Objek mudharabah merupakan konsekuensi logis dengan dilakukannya akad mudharabah.

Modal:

a. Modal yang diserahkan dapat berbentuk uang atau aset lainnya (dinilai sebesar nilai wajar), harus jelas jumlah dan jenisnya.

b. Modal harus tunai dan tidak utang. Tanpa adanya setoran modal, berarti pemilik dana tidak memberikan kontribusi apa pun padahal pengelola dana harus bekerja.

c. Modal harus diketahui dengan jelas jumlahnya sehingga dapat dibedakan dari keuntungan.

d. Pengelola dana tidak diperkenankan untuk memudharabahkan kembali modal mudharabah, dan apabila terjadi maka dianggap terjadi pelanggaran kecuali atas seijin pemilik dana. 
Analisis Pengaruh FDR, NPF, Tingkat Bagi Hasil, Kualitas Jasa

e. Pengelola dana tidak diperbolehkan untuk meminjamkan modal kepada orang lain dan apabila terjadi maka dianggap terjadi pelanggaran kecuali atas seijin pemilik dana.

f. Pengelola dana memiliki kebebasan untuk mengatur modal menurut kebijaksanaan dan pemikirannya sendiri, selama tidak dilarang secara syariah.

Kerja:

a. Kontribusi pengelola dana dapat berbentuk keahlian, keterampilan, selling skill, management skill, dan lain-lain.

b. Kerja adalah hak pengelola dana tidak boleh diintervensi oleh pemilik dana.

c. Pengelola dana harus menjalankan usaha sesuai dengan syariah.

d. Pengelola dana harus mematuhi semua ketetapan yang ada dalam kontrak.

e. Dalam hal pemilik dana tidak melakukan kewajiban atau melakukan pelanggaran terhadap kesepakatan, pengelola dana sudah menerima modal dan sudah bekerja maka pengelola dana berhak mendapatkan imbalan/ganti rugi/upah.

3. Ijab Kabul

Ijab Kabul adalah pernyataan dan ekspresi saling rida/rela di antara pihak-pihak pelaku akad yang dilakukan secara verbal, tertulis, melalui korespondensi atau menggunakan cara-cara komunikasi modern.

4. Nisbah Keuntungan

a. Nisbah adalah besaran yang digunakan untuk pembagian keuntungan, mencerminkan imbalan yang berhak diterima oleh kedua pihak yang bermudharabah atas keuntungan yang diperoleh. Pengelola dana mendapatkan imbalan atas penyertaan modalnya. Nisbah keuntungan harus diketahui dengan jelas oleh kedua pihak, inilah yang akan mencegah terjadinya perselisihan antara kedua belah pihak mengenai cara pembagian keuntungan. Jika memang dalam akad tersebut tidak dijelaskan masing- masing porsi, maka pembagiannya menjadi 50\% dan $50 \%$. 
b. Perubahan nisbah harus berdasarkan kesepakatan kedua belah pihak.

c. Pemilik dana tidak boleh meminta pembagian keuntungan dengan menyatakan nilai nominal tertentu karena dapat menimbulkan riba.

Pada dasarnya pengelola dana tidak diperkenankan untuk memudharabahkan kembali modal mudharabah, dan apabila terjadi maka dianggap terjadi pelanggaran kecuali atas seijin pemilik dana. Apabila pengelola dana diperbolehkan oleh pemilik dana untuk memudharabahkan kembali modal mudharabah maka pembagian keuntungan untuk kasus seperti ini, pemilik dana mendapatkan keuntungan sesuai dengan kesepakatan antara dia dan pengelola dana pertama. Sementara itu bagian keuntungan dari pengelola dana pertama dibagi dengan pengelola dana yang kedua sesuai dengan porsi bagian yang telah disepakati antara keduanya.

\section{Jenis Akad Mudharabah}

Dalam PSAK, mudharabah diklasifikasikan ke dalam tiga jenis yaitu mudharabah muthlaqah, mudharabah muqayyadah, dan mudharabah musytarakah. Berikut adalah pengertian masing-masing jenis mudharabah:

1. Mudharabah Muthlaqah adalah mudharabah di mana pemilik dananya memberikan kebebasan kepada pengelola dana dalam pengelolaan investasinya. Mudharabah ini disebut juga investasi tidak terikat. Jenis mudharabah ini tidak ditentukan masa berlakunya, di daerah mana usaha tersebut akan dilakukan, tidak ditentukan line of trade, line of industry, atau line of service yang akan dikerjakan. Namun kebebasan ini bukan kebebasan yang tak terbatas sama sekali. Modal yang ditanamkan tetap tidak boleh digunakan untuk membiayai proyek atau investasi yang dilarang oleh Islam seperti untuk keperluan spekulasi, perdagangan minuman keras (sekali pun memperoleh ijin dari pemerintah), peternakan babi, atau pun berkaitan dengan riba dan lain sebagainya. Dalam mudharabah muthlaqah, pengelola dana memiliki kewenangan untuk melakukan apa saja dalam pelaksanaan bisnis bagi keberhasilan tujuan Mudharabah itu. Namun, apabila ternyata pengelola dana 
Analisis Pengaruh FDR, NPF, Tingkat Bagi Hasil, Kualitas Jasa melakukan kelalaian atau kecurangan, maka pengelola dana harus bertanggung jawab atas konsekuensi-konsekuensi yang ditimbulkannya. Sedangkan apabila terjadi kerugian atas usaha itu, yang bukan karena kelalaian dan kecurangan pengelola dana maka kerugian itu akan ditanggung oleh pemilik dana.

2. Mudharabah Muqayyadah adalah mudharabah di mana pemilik dana memberikan batasan kepada pengelola antara lain mengenai dana, mengenai lokasi, cara, dan atau objek investasi atau sektor usaha. Misalnya, tidak mencampurkan dana yang dimiliki oleh pemilik dana dengan dana lainnya, tidak menginvestasikan dananya pada transaksi penjualan cicilan tanpa penjamin atau mengharuskan pengelola dana untuk melakukan investasi sendiri tanpa melalui pihak ketiga, (PSAK par 07). Mudharabah ini disebut juga investasi terikat. Apabila pengelola dana bertindak bertentangan dengan syarat-syarat yang diberikan oleh pemilik dana, maka pengelola dana harus bertanggung jawab atas konsekuensi-konsekuensi yang ditimbulkannya, termasuk konsekuensi keuangan.

3. Mudharabah Musytarakah adalah mudharabah di mana pengelola dana menyertakan modal atau dananya dalam kerja sama investasi. Di awal kerja sama, akad yang disepakati adalah akad mudharabah dengan modal 100\% dari pemilik dana, setelah berjalannya operasi usaha dengan pertimbangan tertentu dan kesepakatan dengan pemilik dana, pengelola dana ikut menanamkan modalnya dalam usaha tersebut, jenis Mudharabah seperti ini disebut mudharabah musytarakah merupakan perpaduan antara akad mudharabah dan akad musyarakah.

\section{Penetapan Nisbah Bagi Hasil Pembiayaan}

Bank Syariah menerapkan Nisbah Bagi Hasil terhadap produkproduk pembiayaan yang berbasis Natural Uncertainty Contracts (NUC), yakni akad bisnis yang tidak memberikan kepastian pendapatan (return), baik dari segi jumlah (amount) maupun waktu (timing), seperti mudharabah dan musyarakah. 
Menurut Karim (2007) penetapan nisbah bagi hasil pembiayaan ditentukan dengan mempertimbangkan sebagai berikut:

1. Referensi tingkat (marjin) keuntungan

Yang dimaksud referensi tingkat (marjin) keuntungan adalah referensi tingkat (marjin) keuntungan yang ditetapkan oleh rapat ALCO.

2. Perkiraan tingkat keuntungan bisnis/proyek yang dibiayai.

Perkiraan tingkat keuntungan bisnis/proyek yang dibiayai dihitung dengan mempertimbangkan sebagai berikut:

a. Perkiraan Penjualan:

1) Volume penjualan setiap transaksi atau volume penjualan setiap bulan

2) Sales Turn-Over atau frekuensi penjualan setiap bulan

3) Fluktuasi harga penjualan

4) Rentang harga penjualan yang dapat dinegosiasikan

5) Marjin keuntungan setiap transaksi

b. Lama Cash to cash cycle:

1) Lama proses barang

2) Lama persediaan

3) Lama piutang

c. Perkiraan Biaya-biaya Langsung

Yang dimaksud biaya-biaya langsung adalah biaya yang langsung berkaitan dengan kegiatan penjualan seperti biaya pengangkutan, biaya pengemasan, dan biaya-biaya lain yang lazim dikategorikan dalam cost of goods sold (COGS).

d. Perkiraan Biaya-biaya Tidak Langsung

Yang dimaksud biaya-biaya tidak langsung adalah biaya yang tidak langsung berkaitan dengan kegiatan penjualan, seperti biaya sewa 
Analisis Pengaruh FDR, NPF, Tingkat Bagi Hasil, Kualitas Jasa

kantor, biaya gaji karyawan, dan biaya-biaya lain yang lazim dikategorikan dalam overhead cost (OHC).

e. Delayed Factor

Delayed Factor adalah tambahan waktu yang ditambahkan pada cash to cash cycle untuk mengantisipasi timbulnya keterlambatan pembayaran dari nasabah ke bank.

2. Penentuan Nisbah Bagi Hasil Pendapatan

Dalam hal ini, nisbah bagi hasil pembiayaan untuk bank ditentukan berdasarkan pada perkiraan pendapatan yang diperoleh nasabah dibagi dengan referensi tingkat keuntungan yang telah ditetapkan dalam rapat ALCO. Perkiraan tingkat pendapatan bisnis/proyek yang dibiayai dihitung dengan mempertimbangkan:
a. Perkiraan Penjualan
b. Lama cash to cash cycle
c. Perkiraan Biaya-biaya Langsung (COGS)
d. Delayed Factor

3. Penentuan Nisbah Bagi Hasil Penjualan

Dalam hal ini, nisbah bagi hasil pembiayaan untuk bank ditentukan berdasarkan pada perkiraan penerimaan penjualan yang diperoleh nasabah dibagi dengan pokok pembiayaan dan referensi tingkat keuntungan yang telah ditetapkan dalam rapat ALCO. Perkiraan penerimaan penjualan dihitung dengan mempertimbangkan:
a. Perkiraan Penjualan
b. Lama cash to cash cycle
c. Delayed Factor

Sedangkan untuk penentuan angsuran pokok dilakukan dengan cara sebagai berikut: 
1. Pembiayaan Berjangka Waktu di bawah Satu Tahun

Pembayaran pokok pembiayaan dengan jangka waktu kurang dari satu tahun dapat dilakukan pada saat jatuh tempo.

2. Pembiayaan Berjangka Waktu di atas Satu Tahun

Pembayaran pokok pembiayaan dengan jangka waktu lebih dari satu tahun wajib diangsur secara proporsional selama jangka waktu

pembiayaan.

Yang dimaksud dengan proporsional adalah pembayaran angsuran sesuai dengan arus kas (net cash inflow) dari usaha nasabah.

\section{Financing to Deposit Ratio (FDR)}

Dendiwijaya (2005) Loan to Deposit Ratio (LDR) menyatakan seberapa jauh kemampuan bank dalam membayar kembali penarikan dana yang dilakukan deposan dengan mengandalkan kredit yang diberikan sebagai sumber likuiditas-nya.

Pratama (2011) menjelaskan bahwa LDR sendiri merupakan indikator dalam pengukuran fungsi intermediasi perbankan di Indonesia. Sesuai dengan Surat Edaran Bank Indonesia No. 6/23/DPNP tanggal 31 Mei 2004, rasio LDR dihitung dari pembagian kredit yang diberikan kepada pihak ketiga (tidak termasuk antar bank) dengan Dana Pihak Ketiga (DPK) yang mencakup giro, tabungan, dan deposito. Semakin tinggi LDR menunjukkan semakin besar pula DPK yang dipergunakan untuk penyaluran kredit, yang berarti bank telah mampu menjalankan fungsi intermediasinya dengan baik. Di sisi lain LDR yang terlampau tinggi dapat menimbulkan risiko likuiditas bagi bank.

Perry Warjiyo (2004) dalam Meydianawathi (2007) menerangkan bahwa LDR mempengaruhi penawaran kredit yang dilakukan oleh pihak bank. Semakin tinggi nilai LDR pada suatu bank, maka pihak bank akan menurunkan jumlah penawaran kredit yang dilakukan.

Dalam perbankan syariah tidak ada istilah kredit (loan), yang ada adalah pembiayaan (financing). Sehingga dalam perbankan syariah LDR 
Analisis Pengaruh FDR, NPF, Tingkat Bagi Hasil, Kualitas Jasa

disebut sebagai FDR. Financing to deposit ratio (FDR) merupakan kemampuan bank dalam mengembalikan dana yang telah digunakan untuk suatu pembiayaan dengan menggunakan dana yang berasal dari hasil pembiayaan tersebut, cara menghitungnya dengan cara membagi jumlah pembiayaan yang disalurkan terhadap total dana. Berikut ini adalah cara menghitungnya :

FDR $=$ Jumlah Pembiayaan yang Disalurkan $\times 100 \%$

Total Dana

\section{Non Performing Financing (NPF)}

Arisandi (2011) menyatakan bahwa NPL merupakan persentase jumlah kredit bermasalah terhadap total kredit yang dikeluarkan bank. Semakin besar tingkat NPL ini menunjukkan bahwa bank tersebut tidak profesional dalam pengelolaan kreditnya, sekaligus memberikan indikasi bahwa tingkat risiko atas pemberian kredit pada bank tersebut cukup tinggi searah dengan tingginya NPL yang dihadapi bank.

Sentausa (2009) dalam Pratama (2011) juga menjelaskan bahwa akibat tingginya NPL perbankan harus menyediakan pencadangan yang lebih besar, sehingga pada akhirnya modal bank ikut terkikis. Padahal besaran modal bank sangat mempengaruhi besarnya ekspansi kredit. Besarnya NPL menjadi salah satu penyebab sulitnya perbankan dalam menyalurkan kredit.

Dalam perbankan syariah tidak ada istilah kredit (loan), yang ada adalah pembiayaan (financing). Sehingga dalam perbankan syariah NPL disebut sebagai NPF. Non performing financing (NPF) menurut Maryanah (2006) rasio yang menggambarkan persentase pembiayaan bagi hasil bermasalah terhadap total pembiayaan yang diberikan oleh bank. Semakin besar porsi pembiayaan bermasalah karena adanya keraguan atas kemampuan debitur dalam membayar kembali pinjamannya, semakin besar pula kebutuhan biaya penyisihan kerugian pembiayaan yang nantinya akan berpengaruh pada keuntungan yang diperoleh bank. Menurut Anggraini (2005) NPF merupakan perbandingan antara jumlah pembiayaan yang bermasalah dengan jumlah total pembiayaan. Peningkatan jumlah NPF 
akan meningkatkan jumlah PPAP yang perlu dibentuk oleh pihak bank. Jika hal ini berlangsung terus menerus maka akan mengurangi modal bank. Karena NPF dapat mengurangi jumlah modal, maka secara logika peningkatan nilai NPF akan menurunkan jumlah pembiayaan dalam hal ini adalah mudharabah dan musyarakah.

Christie (2007) juga menjelaskan bahwa apabila terjadi peningkatan jumlah pembiayaan bermasalah (Non Performing Financing / NPF) maka akan menurunkan jumlah pembiayaan, yang dalam hal ini adalah pembiayaan mudharabah. Berikut adalah rumus untuk mencari NPF :

NPF $=$ Jumlah Pembiayaan Bermasalah $\times 100 \%$

Total Pembiayaan

\section{Tingkat Bagi Hasil}

Ikatan Akuntansi Indonesia (2002) dalam Maryanah (2006) menjelaskan bahwa bagi hasil (profit sharing) adalah pembagian keuntungan dihitung dari pendapatan setelah dikurangi beban yang berkaitan dengan pengelolaan dana. Serta nisbah adalah rasio atau perbandingan pembagian keuntungan (bagi hasil) antara shabibul maal (pemilik dana) dan mudharib (pengelola dana).

Maryanah (2006) juga menjelaskan bahwa semakin besar jumlah pendapatan bagi hasil yang diterima oleh bank maka semakin besar pula keinginan bank untuk memberikan pembiayaan bagi hasil. Sebaliknya semakin kecil jumlah pendapatan bagi hasil yang diterima oleh bank maka akan semakin kecil keinginan bank untuk memberikan pembiayaan bagi hasil.

Tingkat bagi hasil merupakan proporsi pembagian hasil usaha yang akan diterima oleh kedua belah pihak yang melakukan perjanjian pembiayaan mudharabah. Besarnya proporsi bagi hasil sesuai dengan kesepakatan yang telah disepakati kedua pihak tersebut di awal akad. Bagi hasil dalam sistem perbankan syari'ah merupakan ciri khusus yang ditawarkan kapada masyarakat, dan di dalam aturan syari'ah yang berkaitan dengan pembagian hasil usaha harus ditentukan terlebih dahulu pada awal 
Analisis Pengaruh FDR, NPF, Tingkat Bagi Hasil, Kualitas Jasa

terjadinya kontrak (akad). Besarnya penentuan porsi bagi hasil antara kedua belah pihak ditentukan sesuai kesepakatan bersama, dan harus terjadi dengan adanya kerelaan (an-tarodbin) di masing-masing pihak tanpa adanya unsur paksaan. Semakin besar tingkat bagi hasil yang dihasilkan dalam pembiayaan mudharabah maka akan merangsang terciptanya akad bagi hasil tersebut, sehingga berpengaruh pada peningkatan jumlah pembiayaan mudharabah yang disalurkan.

\section{Kualitas Layanan}

Kualitas adalah sebuah kata yang bagi penyedia jasa merupakan sesuatu yang harus dikerjakan dengan baik. Aplikasi kualitas sebagai sifat dari penampilan produk atau kinerja merupakan bagian utama strategi perusahaan dalam rangka meraih keunggulan yang berkesinambungan, baik sebagai pemimpin pasar ataupun strategi untuk terus tumbuh.

Keunggulan suatu produk jasa adalah tergantung dari keunikan serta kualitas yang diperlihatkan oleh jasa tersebut, apakah sudah sesuai dengan harapan dan keinginan pelanggan. Menurut kutipan yang disampaikan oleh Philip Kotler, terdapat beberapa macam jasa. Yaitu:

1. Barang berwujud murni. Di sini hanya terdiri dari barang berwujud seperti sabun, pasta gigi. Tidak ada jasa yang menyertai produk tersebut.

2. Barang berwujud yang disertai jasa. Di sini tediri dari barang berwujud yang disertai dengan satu atau lebih jasa untuk mempertinggi daya tarik pelanggan. Contohnya: perbankan tidak hanya menjual produknya saja, melainkan juga kualitas dan pelayanan kepada pelanggannya.

3. Campuran. Di sini terdiri dari barang dan jasa dengan proporsi yang sama. contohnya: perbankan yang harus didukung oleh produk dan pelayanannya.

4. Jasa utama yang disertai barang dan jasa tambahan. Di sini terdiri dari jasa utama dengan jasa tambahan atau barang pelengkap. Contoh: penumpang pesawat terbang membeli jasa transportasi. Mereka sampai di tempat tujuan tanpa sesuatu hal berwujud yang memperlihatkan pengeluaran 
mereka. Namun, perjalanan tersebut memiliki barang-barang berwujud, seperti makanan dan minuman, potongan tiket dan majalah penerbangan. Jasa tersebut membutuhkan barang padat modal (pesawat udara) agar terealisasi, tapi komponen utamanya adalah jasa.

5. Jasa murni. Di sini hanya terdiri dari jasa. Contohnya adalah: jasa menjaga bayi, psikoterapi.

Akibat dari adanya macam-macam jasa ini, maka sulit untuk menyamaratakan jasa, kecuali dengan pembedaan lebih lanjut, yaitu:

1. Berdasarkan basis peralatan/basis orang. Contohnya: pencuci mobil otomatis, mesin berjalan, jasa akuntansi.

2. Kehadiran klien. Contohnya: pada pembedahan otak, pasien harus hadir, potong rambut.

3. Kebutuhan bisnis. Dokter akan menetapkan harga yang berbeda untuk pasien perorangan dan kelompok karyawan perusahaan.

4. Penyedia jasa berbeda dalam sasarannya (laba atau nirlaba) dan kepemilikan (swasta atau publik).

Parasuraman, Zeithaml dan Berry (1991) membentuk model mutu pelayanan yang menyoroti syarat-syarat utama yang memberikan mutu pelayanan yang diharapakan. Adapun model ini mengidentifikasikan lima kesenjangan yang mengakibatkan kegagalan penyampaian jasa, yaitu :

1. Kesenjangan antara harapan konsumen dan persepsi manajemen. Dalam hal ini manajeman tidak selalu memahami benar apa yang menjadi keinginan pelanggan.

2. Kesenjangan antara persepsi manajemen dan spesifikasi mutu pelayanan. Dalam hal ini manajemen mungkin benar dalam memahami keinginan pelanggan, tetapi tidak menetapkan standar pelaksanaan yang spesifik.

3. Kesenjangan antara spesifikasi mutu pelayanan dan penyampaian jasa. Dalam hal ini para personel mungkin tidak terlatih baik dan tidak mampu memenuhi standar. 
Analisis Pengaruh FDR, NPF, Tingkat Bagi Hasil, Kualitas Jasa

4. Kesenjangan antara penyampaian jasa dan komunikasi eksternal. Dalam hal ini harapan konsumen dipengaruhi oleh pernyataan yang dibuat wakilwakil dan iklan perusahaan.

5. Kesenjangan antara jasa yang dialami dan jasa yang diharapkan. Dalam hal ini terjadi bila konsumen mengukur kinerja perusahaan dengan cara yang berbeda dan memiliki persepsi yang keliru mengenai mutu pelayanan.

Parasuraman, dkk. (1991) menjelaskan kualitas pelayanan sebagai fungsi harapan pelanggan pada pra pembelian, pada proses penyediaan kualitas yang diterima, dan pada kualitas output yang diterima. Baik tidaknya kualitas jasa tergantung pada kemampuan penyedia jasa dalam memenuhi harapan pelanggannya secara konsisten (Tjiptono, 2005). Gefen (2002) dalam Wijayanti (2008) juga berpendapat bahwa kualitas pelayanan sebagai perbandingan subyektif yang dibuat konsumen antara kualitas pelayanan yang diterima dan apa yang didapatkan secara aktual.

Kualitas pelayanan yang diberikan kepada konsumen harus sesuai dengan yang diharapkan konsumen. Kualitas pelayanan terutama yang diberikan oleh seluruh staf yang ada pada perusahaan menunjukkan dedikasi yang tinggi dari seluruh staf sesuai arahan yang diberikan pimpinan perusahaan. Total kualitas pelayanan bagi keseluruhan manajemen pemasaran mulai dari seluruh atribut produk atau jasa sampai dengan purna jual telah mendapat perhatian prima dari perusahaan (Muslich, 2007). Parasuraman,dkk (1991) menjelaskan bahwa untuk menetapkan kualitas pelayanan yang ingin dicapai oleh sebuah organisasi jasa, terlebih dahulu organisasi tersebut harus mempunyai tujuan yang jelas. Kualitas pelayanan sendiri merupakan tingkat keunggulan yang diharapkan dan pengendalian atas tingkat keunggulan tersebut untuk memenuhi keinginan pelanggan

\section{Atribut Produk Islam}

Atribut berupa fitur produk yang dimiliki Bank Umum Syariah, diadopsi dari hasil penelitian Iqbal (1997) berupa prinsip-prinsip dasar sistem keuangan Islam yang berasal dari Al-Quran dan As-Sunnah. Prinsip-prinsip dasar tersebut dapat disimpulkan sebagai berikut: 
1. Pengharaman Bunga

Pengharaman bunga/ riba diinterpretasikan sebagai setiap tambahan modal yang tidak adil baik dalam hutang maupun pertukaran antar barang yang diharamkan jika tidak diserahkan dalam jumlah yang sama dan dalam waktu itu juga. Larangan ini didasarkan pada argumentasi keadilan sosial, kesetaraan, dan hak milik. Islam menghalalkan laba jual beli dan mengharamkan bunga. Islam juga mengajarkan berbagi keuntungan serta kerugian dengan cara yang adil.

2. Pembagian Risiko

Pemberi dana dan pengelola dana menerima imbalan saham dari keuntungan dan juga risiko.

3. Uang Sebagai Modal Potensial

Uang diperlakukan sebagai modal potensial hanya pada saat modal aktual digunakan untuk aktivitas produktif.

4. Larangan Perilaku Spekulatif

Sebuah sistem keuangan Islam melarang transaksi yang menampilkan ketidakpastian yang ekstrim, perjudian, dan risiko.

5. Kehalalan Kontrak

Islam menjunjung tinggi kewajiban kontrak dan pengungkapan informasi sebagai bentuk ibadah.

6. Kegiatan Sesuai Syariah

Hanya kegiatan usaha yang tidak melanggar aturan syariah yang memenuhi syarat untuk investasi.

Prinsip-prinsip dasar dalam sistem keuangan Islam yang dikemukakan oleh Iqbal (1997), dalam penelitian ini dijadikan sebagai atribut produk khas yang seharusnya ada pada produk bank syariah, diantaranya: (1) Tidak ada unsur riba, (2) Menggunakan sistem bagi hasil, (3) Tidak ada unsur ketidakpastian (ghoror), (4) Tidak ada unsur judi (maysir), (5) Digunakan untuk investasi yang halal. Atribut-atribut produk khas tersebut yang menjadi alasan pokok para nasabah yang beragama Islam memilih menggunakan bank syariah 
Analisis Pengaruh FDR, NPF, Tingkat Bagi Hasil, Kualitas Jasa

dan menjadi indikator penilaian bagi nasabah. Jika atribut-atribut khas tersebut melekat pada Bank Umum Syariah dan dirasakan manfaatnya oleh nasabah maka nasabah akan memberikan penilaian positif atas atribut produk Islam tersebut.

Berdasarkan penjelasan di atas, pengaruh FDR, NPF, tingkat bagi hasil, Kualitas Layanan dan Atribut Produk Islam terhadap mudharabah, dapat digambarkan dalam sebuah kerangka pikir seperti berikut:

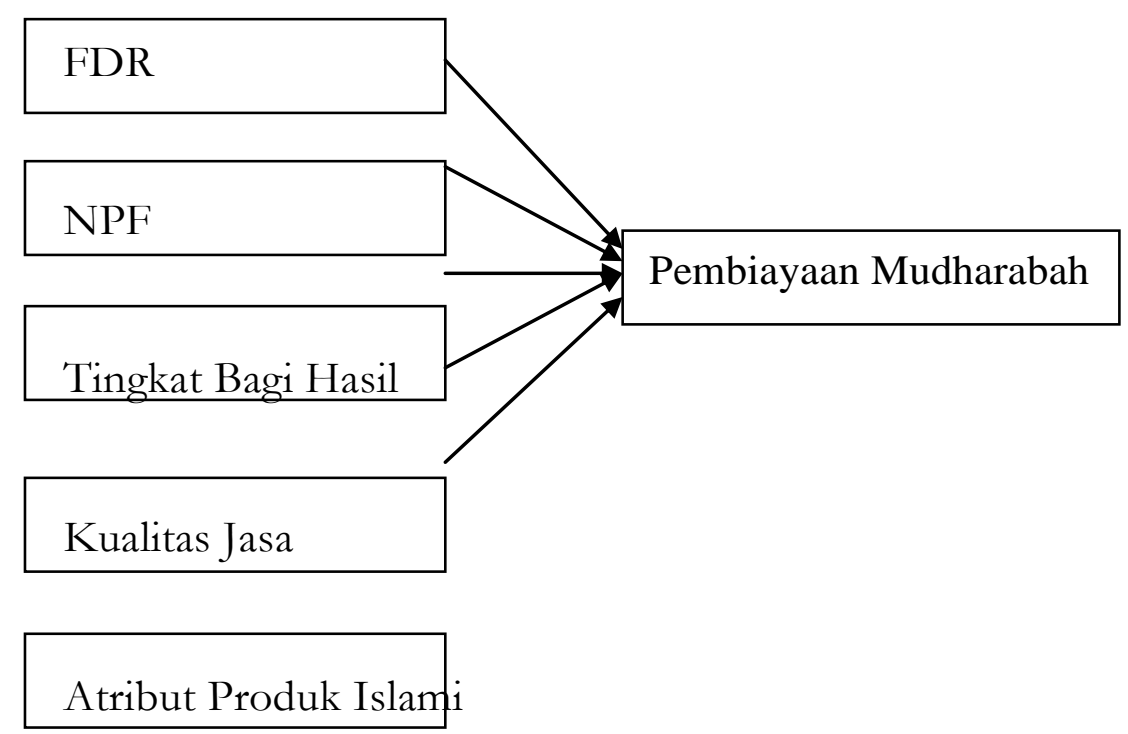

Gambar 2.2. Kerangka Pemikiran Teoritis

\section{Pengembangan Hipotesis}

Hipotesis merupakan jawaban sementara atau dugaan sementara terhadap suatu penelitian. Berdasarkan penjelasan dan kerangka pemikiran di atas, maka dapat dibuat hipotesis sebagai berikut :

H1 : FDR, NPF, tingkat bagi hasil, Kualitas Jasa dan Atribut Produk Islam terhadap pembiayaan mudharabah

H2: FDR berpengaruh positif terhadap pembiayaan mudharabah 
H3 : NPF berpengaruh negative terhadap pembiayaan mudharabah H4 : Tingkat bagi hasil berpengaruh positif pembiayaan mudharabah H5 : Kualitas Jasa Layanan berpengaruh positif terhadap pembiayaan mudharabah

H6 : Atribut Produk Islam berpengaruh positif terhadap pembiayaan mudharabah

pengambilan sampel menunjukan bahwa dari 11 BUS yang ada di Indonesia, ternyata yang memenuhi kriteria sampel ada 8 Bank Umum Syariah. Data BUS. Selanjutnya dari 8 Bank tersebut, dalam rangka pengumpulan data primer berupa jawaban responden nasabah BUS dikota Semarang ditetapkan jumlah responden sebanyak 20 orang pada masingmasing BUS atau dengan total responden untuk 8 BUS sebanyak 160 orang nasabah. Sedangkan pengumpulan data sekunder berupa data rasio keuangan dilihat dari laporan publikasi keuangan Bank Umum Syariah.

Tabel 3

\section{Hasil Perhitungan Regresi Parsial}

\section{Coefficients $^{\mathrm{a}}$}

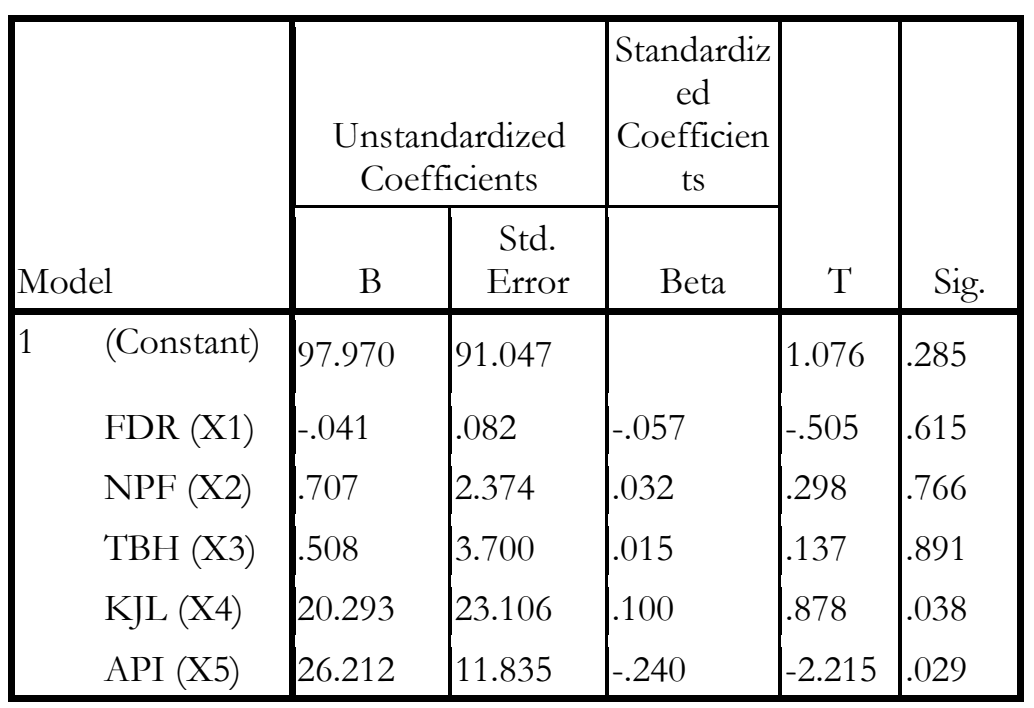

a. Dependent Variable: PM

(Y)

Sumber : Data diolah 2014

Volume V/Edisi 2/Oktober 2014 
Analisis Pengaruh FDR, NPF, Tingkat Bagi Hasil, Kualitas Jasa

Berdasarkan tabel 4.11 dapat dirumuskan persamaan regresi sebagai berikut :

$\mathrm{Y}=97.970-0.41 \mathrm{FDR}+0,707 \mathrm{NPF}+0.508 \mathrm{TBH}+20.293 \mathrm{KJL}+$ 26.212 API

Tabel 5

Hasil Uji Hipotesis

\begin{tabular}{|c|c|c|c|c|}
\hline $\mathrm{No}$ & Hipotesis & Keterangan & Kesimpulan & Hasil \\
\hline 1 & H1 & $\begin{array}{l}\text { FDR, NPF, TBH, } \\
\text { KJL dan API secara } \\
\text { simultan berpengaruh } \\
\text { terhadap Pembiayaan } \\
\text { Mudharabah }\end{array}$ & Diterima & $\begin{array}{l}\text { nilai } \\
\text { signifikansi } \\
0,000 \quad \text { lebih } \\
\text { kecil dari 0,05 }\end{array}$ \\
\hline 2 & $\mathrm{H} 2$ & $\begin{array}{lr}\text { FDR } & \text { berpengaruh } \\
\text { signifikan } & \text { positif } \\
\text { secara } & \text { parsial } \\
\text { terhadap Pembiayaan } & \text { Pemdharabah }\end{array}$ & Ditolak & $\begin{array}{l}\text { nilai } \\
\text { signifikansi } \\
0,615 \quad \text { lebih } \\
\text { besar dari } \\
0,05\end{array}$ \\
\hline 3 & H3 & $\begin{array}{lr}\text { NPF } & \text { berpengaruh } \\
\text { signifikan } & \text { negatif } \\
\text { secara } & \text { parsial } \\
\text { terhadap } & \text { Pembiayaan } \\
\text { Mudharabah }\end{array}$ & Ditolak & \begin{tabular}{l} 
nilai \\
\multicolumn{2}{l}{ signifikansi } \\
$0,766 \quad$ lebih \\
besar dari \\
0,05
\end{tabular} \\
\hline 4 & H4 & $\begin{array}{lr}\text { TBH } & \text { berpengaruh } \\
\text { signifikan } & \text { positif } \\
\text { secara } & \text { parsial } \\
\text { terhadap } & \text { Pembiayaan } \\
\text { Mudharabah }\end{array}$ & Ditolak & $\begin{array}{l}\text { nilai } \\
\text { signifikansi } \\
0,891 \quad \text { lebih } \\
\text { besar dari } \\
0,05\end{array}$ \\
\hline 5 & H5 & $\begin{array}{lr}\text { KJL } & \text { berpengaruh } \\
\text { signifikan } & \text { positif } \\
\text { secara } & \text { parsial } \\
\text { terhadap } & \text { Pembiayaan } \\
\text { Mudharabah }\end{array}$ & Diterima & $\begin{array}{l}\text { nilai } \\
\text { signifikansi } \\
0,311 \quad \text { lebih } \\
\text { besar dari } \\
0,05\end{array}$ \\
\hline 6 & H6 & $\begin{array}{lr}\text { API } & \text { berpengaruh } \\
\text { signifikan } & \text { positif } \\
\text { secara } & \text { parsial } \\
\text { terhadap } & \text { Pembiayaan } \\
\text { Mudharabah }\end{array}$ & Diterima & $\begin{array}{l}\text { nilai } \\
\text { signifikansi } \\
0,29 \quad \text { lebih } \\
\text { kecil dari } 0,05\end{array}$ \\
\hline
\end{tabular}

\section{Koefisen Determinasi $\left(\mathbf{R}^{2}\right)$}

Koefisien determinasi $\left(R^{2}\right)$ pada intinya mengukur seberapa jauh kemampuan model dalam menerangkan variasi variabel dependen. Koefisien determinasi merupakan kemampuan prediksi dari keenam variabel independen 
FDR, NPF, TBH, KJL dan API berpengaruh secara bersama-sama terhadap Pembiayaan Mudharabah. Dari tampilan output SPSS pada tabel 4.13 nilai koefisien determinasi (Adjusted $\mathrm{R}^{2}$ ) sebesar 0.31 atau 31\% hal ini berarti 31\% variasi Pembiayaan Mudharabah dapat dijelaskan oleh variasi dari kelima FDR, NPF, TBH, KJL dan API. Sedangkan sisanya $(100 \%-31 \%=69 \%)$ dijelaskan oleh sebab-sebab atau variabel yang lain diluar model.

\section{Tabel 4.13}

Koefisien Determinasi (Adjusted $\boldsymbol{R}^{2}$ )

\begin{tabular}{|l|l|l|l|l|}
\hline Model & \multicolumn{1}{|c|}{$\mathrm{R}$} & $\mathrm{R}$ Square & $\begin{array}{c}\text { Adjusted R } \\
\text { Square }\end{array}$ & $\begin{array}{c}\text { Std. Error of } \\
\text { the Estimate }\end{array}$ \\
\hline 1 & $.231^{\mathrm{a}}$ & .54 & .31 & 34.19889 \\
\hline
\end{tabular}

b. Dependent Variable: PM (Y)

Sumber : Data diolah 2014

\section{Pembahasan Uji Hipotesis}

\section{Pengaruh Financing to Deposit Ratio (FDR), dan Non Performing Financing (NPF), Tingkat Bagi Hasil (TBH), Kualitas Jasa Layanan (KJL), dan Atribut Produk Islam (API) terhadap pembiayaan Mudharabah.}

Rasio keuangan dapat dikatakan bermanfaat jika rasio keuangan dapat digunakan untuk membantu dalam pengambilan keputusan. Manfaat rasio keuangan dalam memprediksi perubahan laba dapat diukur dengan signifikan atau tidaknya hubungan antara rasio keuangan dengan perubahan laba. Apabila hubungan antara rasio keuangan dengan perubahan laba signifikan berarti bahwa rasio keuangan bermanfaat dalam memprediksi perubahan laba, sebaliknya jika hubungan tidak signifikan berarti bahwa rasio keuangan tidak dapat digunakan untuk memprediksi laporan keuangan.

Hasil Analisis FDR, NPF, TBH, KJL dan API berpengaruh secara bersama-sama terhadap Pembiayaan Mudharabah. Hal tersebut dapat dilihat dari tingkat signifikansi sebesar 0,000 lebih kecil dari 0,05. Hal ini sesuai dengan hipotesis yang menyebutkan bahwa rasio FDR, NPF, TBH, KJL dan 
Analisis Pengarub FDR, NPF, Tingkat Bagi Hasil, Kualitas Jasa

API berpengaruh secara bersama-sama terhadap Pembiayaan Mudharabah pada Bank Umum Syariah di Indonesia.

Pengaruh tersebut tergolong rendah dimana semua variabel independen hanya mampu menjelaskan sebesar 31\% terhadap variabel dependen. Hal ini mengindikasikan bahwa sebagian besar variabel dependen ditentukan oleh faktor-faktor lain selain faktor independen FDR, NPF, TBH, KJL dan API, untuk menerangkan faktor-faktor lain yang berpengaruh terhadap pembiayaan mudharabah perlu penelitian lebih lanjut dengan memasukkan faktor-faktor lainnya.

\section{Pengaruh Financing to Deposit Ratio (FDR) terhadap Pembiayaan Mudharabah}

Hasil perhitungan diperoleh hasil signifikansi sebesar 0,615, sedangkan koefisien regresinya sebesar -0.41 . Hal ini menunjukkan bahwa FDR tidak berpengaruh positif terhadap pembiayaan Mudharabah, karena nilai signifikansinya lebih besar dari 0,05 yaitu sebesar 0,615.

Secara Teori hasil penelitian ini tidak sinkron dengan teori yang digunakan dalam penelitian ini yaitu teori stewardship dimana teori yang menjunjung tinggi nilai kepercayaan antara pemilik dana (shabibul maal) dan pengelola dana (mudharib), di mana pemilik dana memberikan kepercayaan kepada pengelola dana untuk mengelola dana tersebut ke dalam suatu usaha yang bersifat produktif. Berdasarkan teori tersebut maka skim pembiayaan yang dapat diterapkan adalah skim pembiayaan mudharabah muqayyadah, yaitu pemilik dana memberikan batasan kepada pengelola dana dalam mengelola dana. Apabila FDR tinggi, diharapkan dengan menggunakan skim pembiayaan mudharabah muqayyadab tersebut, pihak bank tetap dapat mengendalikan dan bahkan juga dapat menaikkan jumlah pembiayaan mudharabah yang disalurkan.

Hasil penelitian ini tidak konsisten dengan hasil penelitian yang dilakukan oleh Perry Warjiyo (2004) dalam Meydianawathi (2007) menerangkan bahwa LDR/FDR mempengaruhi penawaran kredit yang dilakukan oleh pihak bank. Semakin tinggi nilai LDR pada suatu bank, maka pihak bank akan menurunkan jumlah penawaran kredit yang dilakukan atau kalau dalam Bank Syariah Pembiayaan yang disalurkan. 


\section{Pengaruh Non Performing Financing (NPF) terhadap Pembiayaan Mudharabah}

Berdasarkan hasil penelitian, NPF tidak mempunyai pengaruh signifikan positif terhadap Pembiayaan Mudharabah pada Perbankan Syariah. Ditunjukkan dengan tingkat signifikansi diatas 0,05 yaitu sebesar 0,766. yang berarti hipotesis yang menyatakan rasio NPF berpengaruh signifikan positif terhadap Pembiayaan Mudharabah pada Perbankan Syariah di Indonesia di tolak.

Hasil penelitian ini tidak sesuai dengan penelitian yang dilakukan oleh Christie (2007) yang menjelaskan bahwa apabila terjadi peningkatan jumlah pembiayaan bermasalah (Non Performing Financing / NPF) maka akan menurunkan jumlah pembiayaan, yang dalam hal ini adalah pembiayaan mudharabah. Disamping itu hasil ini juga tidak sesuai dengan teori dimana NPF merupakan perbandingan antara jumlah pembiayaan yang bermasalah dengan jumlah total pembiayaan. Peningkatan jumlah NPF akan meningkatkan jumlah PPAP yang perlu dibentuk oleh pihak bank. Jika hal ini berlangsung terus menerus maka akan mengurangi modal bank. Karena NPF dapat mengurangi jumlah modal, maka secara logika peningkatan nilai NPF akan menurunkan jumlah pembiayaan dalam hal ini adalah mudharabah

\section{Pengaruh Tingkat Bagi Hasil (TBH) terhadap Pembiayaan Mudharabah}

Hasil perhitungan diperoleh hasil signifikansi sebesar 0,891,dimana hasilnya menunjukkan bahwa TBH tidak berpengaruh positif terhadap pembiayaan Mudharabah, Secara Teori hasil penelitian ini tidak sinkron dengan teori yang digunakan dalam penelitian ini yaitu Tingkat bagi hasil merupakan cara yang digunakan untuk membagi keuntungan atas suatu pembiayaan syariah. Tingkat bagi hasil yang tinggi dapat memberikan stimulasi yang baik bagi suatu pembiayaan syariah. Jadi semakin tinggi tingkat bagi hasil maka akan memberikan pengaruh yang positif terhadap pembiayaan mudharabah. 
Analisis Pengaruh FDR, NPF, Tingkat Bagi Hasil, Kualitas Jasa

\section{Pengaruh Kualitas Jasa Layanan (KJL) terhadap Pembiayaan Mudharabah}

Berdasarkan hasil penelitian, KJL mempunyai pengaruh signifikan positif terhadap Pembiayaan Mudharabah pada BUS. Ditunjukkan dengan tingkat signifikansi dibawah 0,05 yaitu sebesar 0,038. yang berarti hipotesis yang menyatakan Kualitas Jasa Layanan pada BUS berpengaruh signifikan positif terhadap Pembiayaan Mudharabah pada Perbankan Syariah di Indonesia di terimak.

Hasil penelitian ini sesuai dengan teori yang menyatakan bahwa Kualitas pelayanan yang diberikan kepada konsumen harus sesuai dengan yang diharapkan konsumen. Kualitas pelayanan terutama yang diberikan oleh seluruh staf yang ada pada perusahaan menunjukkan dedikasi yang tinggi dari seluruh staf sesuai arahan yang diberikan pimpinan perusahaan, maka secara logis dapat ditunjukan bahwa kualitas layanan yang diberikan BUS semakin baik selanjutnya akan berdampak positif terhadap ketertarikan nasabah menggunakan layanan Bank dalam hal ini layanan Pembiayaan Mudharabah

\section{Pengaruh Atribut Produk Islam (API) terhadap Pembiayaan Mudharabah}

Berdasarkan hasil penelitian, API menunjukan hasil pengaruh signifikan positif terhadap Pembiayaan Mudharabah pada BUS. Ditunjukkan dengan tingkat signifikansi dibawah 0,05 yaitu sebesar 0,038. yang berarti hipotesis yang menyatakan Kualitas Jasa Layanan pada BUS berpengaruh signifikan positif terhadap Pembiayaan Mudharabah pada Perbankan Syariah di Indonesia di terimak.

Hasil penelitian ini sesuai dengan teori yang menyatakan bahwa Atribut-atribut produk khas tersebut yang menjadi alasan pokok para nasabah yang beragama Islam memilih menggunakan bank syariah dan menjadi indikator penilaian bagi nasabah. Jika atribut-atribut khas tersebut melekat pada Bank Umum Syariah dan dirasakan manfaatnya oleh nasabah maka nasabah akan memberikan penilaian positif atas atribut produk Islam tersebut, maka secara logis dapat ditunjukan bahwa dengan semakin baiknya atribut produk islam yang melekat pada Bank Umum syariah akan memberikan 
keyakinan pada masyarakat untuk menggunkan produk pembiayaan Mudharabah dan damapknya akan meningkat tingkat penyaluran pembiayaan Mudharabah di Bank Umum Syariah.

\section{Kesimpulan}

Berdasarkan hasil pengujian hipotesis terhadap permasalahan yang ada, maka dapat diambil kesimpulan sebagai berikut :

1. Variabel FDR, NPF, Tingkat Bagi Hasil, Kualitas Jasa Layanan dan Atribut Produk Islam berpengaruh signifikan terhadap variabel Pembiayaan Mudharabah.

2. Variabel FDR tidak berpengaruh signifikan positif terhadap variabel Pembiayaan Mudharabah.

3. Variabel NPF tidak berpengaruh signifikan negatif terhadap Pembiayaan Mudharabah.

4. Variabel Tingkat Bagi hasil tidak berpengaruh signifikan positif terhadap Pembiayaan Mudharabah.

5. Variabel Kualitas Jasa Layanan berpengaruh signifikan positif terhadap Pembiayaan Mudharabah.

6. Variabel Atribut Produk Islam berpengaruh signifikan positif terhadap Pembiayaan Mudharabah.

Paparan tersebut menunjukkan bahwa faktor keuangan yakni (FDR, NPF dan Bagi Hasil) ternyata tidak memberikan pengaruh yang signifikan terhadap pembiayaan mudharabah, ini berarti bahwa naik turunnya pemberian pembiayaan mudharabah tidak dipengaruhi oleh faktor keuangan, tetapi malah justru dipengaruhi oleh faktor non keuangan yakni (kualitas jasa layanan dan atribut produk islam).

\section{Saran} berikut :

Saran yang diajukan berdasarkan hasil penelitian adalah sebagai

- Penelitian ini hanya terbatas pada kajian empiris tentang pengaruh FDR, NPF, Tingkat Bagi Hasil, Kualitas Jasa Layanan dan Atribut Produk Islam terhadap variabel Pembiayaan Mudharabah. 
Analisis Pengaruh FDR, NPF, Tingkat Bagi Hasil, Kualitas Jasa

- Penelitian selanjutnya disarankan untuk mengembangkan penelitian ini dengan mempertimbangkan faktor-faktor lain diluar laporan keuangan, seperti factor makro ekonomi dan factor mikro ekonomi yang belum dipertimbangkan dalam penelitian ini, serta menambah rasio-rasio keuangan yang diteliti untuk perluasan penelitian. 


\section{DAFTAR PUSTAKA}

Anggraini, Desti. 2005. "Faktor-faktor yang Mempengaruhi Penawaran Pembiayaan Mudharabah dan Musyarakah". Tesis. Jakarta: UI.

Arisandi, Dewi. 2011. Analisis faktor Penawaran Kredit Pada Bank Umum di Indonesia. Dalam papers.gunadarma.ac.id. Jakarta: Universitas Gunadarma.

Christie, Anita. 2007. "Faktor-faktor yang Mempengaruhi Jumlah Pembiayaan Mudharabah di Bank Muamalat Indonesia (Periode Maret 2001 s.d. Februari 2006)"'. Tesis. Jakarta: UI.

Cleopatra, Yuria Pratiwhi. 2008. Faktor-faktor yang Mempengaruhi Pertumbuhan Proporsi Aset Perbankan Syariah di Indonesia. Dalam Jurnal Ekonomi dan Bisnis. Jakarta: UI.

Dendawijaya, Lukman. 2005. Manajemen Perbankan. Jakarta: Ghalia Indonesia.

Donna, Duddy Roesmara. dan Dumairy. 2006. "Variabel - variabel yang Mempengaruhi Permintaaan dan Penawaran Mudharabah pada Perbankan Syariah di Indonesia". Dalam Sosiosains, Nomor 19. Hal 4 Yogyakarta: UGM.

Ghozali, Imam. 2006. Aplikasi Analisis Multivariate dengan Program SPSS. Semarang: UNDIP.

------. 2007. Aplikasi Analisis Multivariate dengan Program SPSS. Cetakan IV. Semarang: UNDIP.

Hilmi. 2006. "Analisis Faktor-faktor yang Mempengaruhi Pembiayaan Mudharabah pada Bank Syariah Mandiri”. Tesis. Jakarta: UI.

Karim, Adiwarman Azwar. 2007. Bank Islam: Analisis Fiqib dan Keuangan (Edisi Ketiga). Jakarta: PT RajaGrafindo Persada.

Maryanah. 2006. "Analisis Faktor-faktor yang Mempengaruhi Pembiayaan Bagi Hasil di Bank Syariah Mandiri”. Tesis. Jakarta: UI. 
Analisis Pengarub FDR, NPF, Tingkat Bagi Hasil, Kualitas Jasa

Meydianawathi, Luh Gede. 2007. "Analisis Perilaku Penawaran Kredit Perbankan Kepada Sektor UMKM di Indonesia (20022006). Dalam BULETIN STUDI EKONOMI. Volume 12 Nomor 2 Tahun 2007. Denpasar : Universitas Udayana.

Nurhayati, Sri dan Wasilah. 2009. Akuntansi Syariah di Indonesia. Jakarta: Salemba Empat.

Perwataatmadja, Karnaen A dan Hendri Tanjung. 2007. Bank Syariab: Teori, Praktik, dan Peranannya. Jakarta: Celestial Publishing.

Pratama, Billy Arma. 2011. Analisis Faktor-faktor yang Mempengaruhi Kebijakan Penyaluran Kredit Perbankan. Dalam papers.gunadarma.ac.id. Jakarta: Universitas Gunadarma. ratin dan Akhyar Adnan. 2005. "Analisis Hubungan Simpanan, Modal Sendiri,NPL, Prosentase Bagi Hasil dan Markup Keuntungan terhadap Pembiayaan pada Perbankan Syariah (studi kasus pada BMI)". Dalam Sinergi Kajian Manajemen dan Bisnis, Edisi Khusus on Finance. Hal 35-52 Yogyakarta: Balai Diklat Keuangan III Yogyakarta dan FE UII.

Sujatna, Yayat. 2006. “ Analisis Faktor Internal dan Eksternal yang Mempengaruhi Jumlah Pembiayaan Bagi Hasil (Studi Kasus: Bank Syariah Mandiri)". Tesis. Jakarta: UI.

Usamah. 2009. "Peran Kompetensi dan Model Pengorganisasian Dewan Pengawas Syariah Terhadap Pembiayaan Berbasis Bagi Hasil Pada Perbankan Syariah di Indonesia". Dalam Artikel KU. Semarang: Undip. 